\title{
Valparaíso a través de sus revistas: Un modelo de vanguardia heterogénea*
}

\author{
Valparaíso through its magazines: A model of an \\ heterogeneous avant-garde
}

\author{
Begoña Alberdi Soto \\ Pontificia Universidad Católica de Chile. Santiago, Chile \\ balberdi@uc.cl
}

\section{RESUMEN}

El presente trabajo extiende el término heterogeneidad -utilizado acotadamente por el crítico Cornejo Polar para el caso peruano- para intentar definir al tipo de vanguardia que se desarrolló en Valparaíso durante la década del veinte, a través de las revistas Litoral (1927-28) y Nguillatún (1924). El objetivo es particularizar a Chile como un caso aparte de heterogeneidad; un caso cuyo doble estatuto sociocultural surgirá en el desfase, no entre literatura indigenista e indigenismo, sino entre lo tradicional y lo moderno, entre lo culto y la cultura popular o, más ampliamente, entre urbanidad y ruralidad.

Palabras clave: Valparaíso, modernización, revistas artístico-culturales, heterogeneidad.

\section{ABSTRACT}

This work expands the term heterogeneity - used only in the peruvian case by the reviewer Cornejo Polar- and tries to define the kind of avant-garde that carried

* Este trabajo es parte del proyecto Fondecyt $N^{\circ} 1090735$, "La vanguardia chilena en sus revistas (1920-1930): modernidad, poesía e intelectuales", dirigido por Patricio Lizama A., Pontificia Universidad Católica de Chile y fue realizado en el marco del seminario de posgrado Teorías Culturales, a cargo del profesor Danilo Santos. 
out in Valparaíso during de twenties, using the magazines Litoral (1927-28) and Nguillatun (1924). The aim of this work is to particularize Chile as an isolated case of heterogeneity; a case in which double sociocultural status will emerge in the gap, not between indigenism and indigenist, but between tradition and modernity, highbrow and lowbrow or, extensivily, between urbanity and rurality.

Keywords: Valparaíso, modernization, artistic and cultural magazines, heterogeneity.

Recibido: 29.07.2013. Aceptado: 15.10.2013.

\section{INTRODUCCIÓN}

\subsection{La importancia del término heterogeneidad para la crítica literaria latinoamericana}

al como lo emplea la actual crítica cultural latinoamericanista, el tér1 mino heterogeneidad proviene, principalmente, del crítico literario
peruano Antonio Cornejo Polar (1936-1977) y se define como un discurso cuyo productor pertenece a un mundo culturalmente distinto al de su referente: crónicas de la conquista, literatura indigenista, gauchesca, negrista. Desde la perspectiva del pensador peruano, la heterogeneidad proliferaría en aquellos textos que revelan la condición fragmentada y fracturada de las naciones latinoamericanas, condición que se reproduce al interior de su literatura.

En este sentido, el término acuñado por Cornejo Polar (2011) ha resultado sumamente enriquecedor para repensar a América Latina como una totalidad contradictoria, en tanto desplaza la palabra "unidad" por la de "multiplicidad heterogénea". En el caso de América Latina, si su sociedad no es armónica y estática, entonces su literatura tampoco puede serlo. A partir de esta premisa, la problemática del pensamiento crítico latinoamericano se ha desplazado hacia "...la reivindicación de la heteróclita pluralidad [latinoamericana]... poniendo énfasis en las abisales diferencias que separan y contraponen, hasta con beligerancia, a los varios universos socio-culturales" (Cornejo Polar, 2011: 6).

Como tal, el concepto de heterogeneidad emerge en los años sesenta a modo de intervención, por una parte, en la coyuntura política de Perú y el fracaso del concepto de mestizaje y, por otra, como reacción al fenómeno del boom y a la "universalización" de la literatura latinoamericana. Ambos 
elementos generaron un contradiscurso que buscaba -ante todo- reconocer las particularidades culturales e históricas de cada región, insistiendo en que "...solo una literatura que testimonie -sea de forma consciente o inconsciente- esa 'peculariedad diferencial' del ser latinoamericano, puede ser considerada auténticamente representativa” (Szurmuk \& McKee, 2009: 130-1).

La literatura representativa sería aquella que refleja la naturaleza no orgánica de la región, es decir, la fragmentación cultural de dos mundos opuestos o antagónicos: el mundo letrado contra el mundo oral, el urbano contra el rural, el occidental contra el indígena; realidad que se refleja no solo a nivel de contenido sino en la producción textual, es decir, en el nivel del mismo sistema literario. Así entonces, la heterogeneidad permitiría dar cuenta del universo heteróclito de los discursos culturales latinoamericanos $\mathrm{y}$, desde la interdisciplinariedad, explorar las diversas formas expresivas de subculturas regionales.

A partir de los años noventa, Cornejo Polar matiza su concepto, considerando las teorías posestructuralistas del sujeto, el debate sobre las literaturas poscoloniales y la crítica que se le hizo respecto de un cierto estatismo en las nociones de heterogeneidad literaria y sistemas literarios, llegando a plantear que existe una heterogeneidad al interior de cada sistema o nivel del proceso: "Entendí más tarde que la heterogeneidad se infiltraba en la configuración interna de cada una de esas instancias [emisor/discurso-texto/ referente/receptor]" (2011: 10).

La noción de heterogeneidad interna implica una generalización y ampliación de la categoría que va más allá de la literatura indigenista y que la abre al análisis de las literaturas poscoloniales. Con esto, el término culmina por aproximarse a un simple reconocimiento de la diferencia, pluralidad y contradicción que marcan toda identidad, sea individual o colectiva: “... cuando se comienza a discutir la identidad del sujeto y la turbadora posibilidad de que sea un espacio lleno de contradicciones internas, y más relacional que autosuficiente, lo que se pone en debate, o al menos el marco dentro del cual se reflexiona, no es otro que la imagen romántica del yo" (Cornejo Polar, 2011: 11).

A partir de la extensión y flexibilización del término, su ámbito de influencia se extendió más allá de lo andino, encontrando eco incluso en estudios de subalternidad que enjuician, de algún modo, el concepto transculturación ${ }^{1}$ acuñado por Rama (1982). A diferencia de Cornejo Polar (2011),

\footnotetext{
${ }^{1}$ Originalmente acuñado por el antropólogo cubano Fernando Ortiz en los años cuarenta,
} 
para Rama el choque de dos o más universos socioculturales tiene una connotación positiva pues no trae consigo una fractura, sino una unidad cultural o mestizaje. Para Cornejo Polar, en cambio, dichos discursos serán siempre fuerzas en choque, perspectiva que se extenderá a otros pensadores latinoamericanos como Néstor García Canclini (2001) con su concepto de hibridación.

En síntesis, y más allá de las variaciones y especificaciones del término, es el propósito mismo de Cornejo Polar el que, a mí parecer, debe extenderse hacia las distintas zonas y subzonas culturales de cada uno de nuestros países y localidades. Desde Cornejo Polar, la tarea para la crítica latinoamericana consiste en trabajar con objetos literarios que en sí mismos reflejen el carácter plural de nuestra literatura. Serían totalidades conflictivas las ya mencionadas por Cornejo Polar -gauchesca, indigenismo-, pero también las literaturas populares con su mecanismo de reciclaje de los modelos abandonados por el canon. Así, lo interesante de este concepto es que permite auscultar la procedencia histórica de la literatura y la convergencia en ella de dos o más sistemas en un solo proceso literario.

El concepto así introducido resulta de gran relevancia para pensar a Chile como un caso aparte de heterogeneidad, un caso cuyo doble estatuto sociocultural surgirá en el desfase, no tanto entre literatura indigenista e indigenismo, sino entre lo tradicional y lo moderno, entre lo culto y la cultura popular o, más ampliamente, entre urbanidad -la ciudad letrada en términos de Rama (2004) - y ruralidad. El concepto de heterogeneidad permite reconstruir períodos como el de las vanguardias artísticas y literarias, donde generalmente se alude a sus figuras centrales y epónimas y se mencionan solo de manera tangencial a numerosos grupos, artistas e intelectuales que, en realidad, fueron actores fundamentales para el desarrollo y consolidación de las vanguardias. En este contexto, propongo utilizar el concepto de Cornejo Polar para describir algunas subzonas culturales de la década 1920-1930 que ponen de manifiesto el conflicto y la ambigüedad que surge a partir del encuentro de dos estructuras o universos socioculturales diferentes. Haciendo uso de las múltiples revistas artístico-culturales de los años veinte en Chile, quisiera rescatar el espacio de Valparaíso, mediante dos proyectos que ponen en escena dicha fractura: las revistas Nguillatún (1924) y Litoral (1927-8).

pero redefinido y puesto en circulación por Rama, el término "transculturación" es una categoría fundamental en la discusión sobre los encuentros y desencuentros entre tradición y modernidad en el continente. Ver Rama (1982). 


\subsection{Sobre el campo cultural chileno 1920-1930: el caso Valparaíso}

El campo cultural ${ }^{2}$ de la década 1920-1930 está conformado por una trama compleja de intelectuales que poseen diversos capitales culturales, sociales y económicos ${ }^{3}$, lo que trae como consecuencia la proliferación de diferentes y divergentes grupos de vanguardia y una heterogeneidad tanto de discursos como de estrategias de posicionamiento. Sin embargo y a pesar de sus diferencias, todos estos grupos tienen en común un marcado carácter antioligárquico y -en la misma línea de enfrentamiento al poder dominante- todos adscriben a un "arte nuevo", vinculado directamente a los ismos europeos.

En esta década existe una compleja trama de intelectuales en Chile, cada uno amparado bajo un proyecto-revista distinto: por una parte destacan los cosmopolitas y los grupos de Santiago (algunos independientes, otros vinculados al profesorado y a federaciones universitarias) y por otro lado -y como una historia artística e intelectual aparte-, existen numerosas formaciones de provincia, conformadas por jóvenes que en su mayoría no han salido del país, pero que poseen importantes vínculos con intelectuales extranjeros que migran hacia las localidades de tránsito.

Uno de los casos más reveladores de este último grupo es el puerto de Valparaíso, espacio rico en cruces e intersecciones entre propuestas regionales y foráneas, cuyos productos literarios y artísticos han sido escasamente considerados. Por esta razón y por la importancia que revisten para configurar el complejo mapa de la literatura chilena de vanguardia, el objeto de estudio del presente trabajo serán las revistas Litoral (1927-1928) y Nguillatún (1924), proyectos que, si bien fugaces, produjeron importantes modificaciones dentro del campo intelectual de la época.

$\mathrm{Al}$ respecto, cabe mencionar que Valparaíso es un caso especialmente relevante desde la perspectiva del desarrollo vertiginoso de las ciudades a finales del siglo XIX y principios del siglo XX: por un lado es el gran puerto del Pacífico Sur con una intensa actividad portuaria y una población marcadamente cosmopolita, pero, por otro, y debido al aporte de inmigrantes extranjeros y a la carencia de espacio disponible en la zona plana de la ciudad,

\footnotetext{
${ }^{2}$ Pierre Bourdieu (1995) denomina campo cultural o intelectual a un sistema normalizado de diferencias y dispersiones, dentro del cual cada obra singular se define. Corresponde a aquel “... universo sometido a sus propias leyes de funcionamiento y de transformación, es decir la estructura de las relaciones objetivas entre la posición que en él ocupan individuos o grupos situados en situación de competencia por la legitimidad..." (318).

${ }^{3}$ La especificidad de cada campo viene dada, según Bourdieu (1987), por el tipo de recursos que se moviliza en su ámbito. Se da el nombre de capital a los recursos puestos en juego en los diferentes campos: capital social, cultural y económico (11-17).
} 
se generó una vertiginosa ocupación urbano-arquitectónica de sus cerros y una proliferación de viviendas populares, conventillos y ranchos urbanos, lo que explica la imagen del Valparaíso decimonónico que surge de la frase "cerros de conventillos".

Desde esta perspectiva, la particularidad de su grupo de vanguardia reside no solo en el contacto con intelectuales extranjeros ${ }^{4}$, sino en las circunstancias personales de cada uno de sus integrantes: el grupo de Valparaíso no viaja y, si lo hace, no se dirige a la modernidad artística de París sino a la modernidad tecnológica de los Estados Unidos - como es el caso de Neftalí Agrella-, luego, los inmigrantes que se integran a ellos no son los máximos representantes de la vanguardia europea sino marginales dentro de su propia modernidad y muchos de ellos viven hacinados en conventillos -como es el caso del propagandista ruso Marko Smirnoff. Por esta y otras razones, cabe destacar que el grupo de Valparaíso no podía sino articularse como una vanguardia crítica y de compromiso social, alejada de esa otra actitud vanguardista, la del creacionismo y surrealismo, donde el acto creador y la inefabilidad del lenguaje están en primer plano.

\subsection{Las revistas artístico-culturales de vanguardia}

Mediante el discurso artístico de vanguardia, los grupos intelectuales buscan construir un espacio legítimo de representación social, posicionándose en las antípodas del sistema representacional amparado por la oligarquía. Para este propósito, dichos grupos encontrarán en la revista artístico-cultural el medio más eficaz para construir simbólicamente un espacio de representación y de resistencia contrahegemónica. Por ello, más que un mero medio de difusión, las revistas constituyen verdaderos "proyectos intelectuales" de ciertas "formaciones" ${ }^{5}$ que ejercen una intervención aguda, aunque sea breve, en la trama cultural (Patiño, 2008: 147). Tal es el caso de las revistas Litoral -con tres números en total-y Nguillatún -con un solo número de cuatro páginas.

En tanto instrumento de mediación cultural, las revistas constituyen una

${ }^{4}$ Destaca la presencia de los poetas peruanos Magda Portal y Serafín del Mar, la poeta uruguaya Blanca Luz Brum, el poeta húngaro Zsigmond Remenyik, el artista mexicano Jesús Carlos Toro y el propagandista ruso Marko Smirnoff, entre otros.

${ }^{5}$ Las formaciones son definidas por Pierre Bourdieu como agrupaciones intelectuales con un número reducido de miembros, sin reglas y de carácter laxo. Ver: Carlos Altamirano y Beatriz Sarlo. (1984). 
zona de contacto entre políticas culturales hegemónicas y proyectos alternativos, entre creación artística y grupos receptores y, por último, entre el sector intelectual académico y el lector (Moraña, 2004: 240). Además de su carácter de mediación, las revistas constituyen un espacio de difusión independiente, lo que sin duda se acrecienta en los grupos de provincia -pero sobre todo en Valparaíso-, donde existe una estética de la resistencia, la de un lugar excéntrico que lucha por su legitimación y por diferenciarse de la metrópoli central. De este modo, la inclusión de las revistas dentro del corpus de la literatura hispanoamericana permite trazar nuestra literatura como una totalidad contradictoria, con una multiplicidad de formaciones culturales regionales con capacidad de resistencia y reconstitución, lo que no hace más que evidenciar -como era la intención de Cornejo Polar- el fracaso de concebir a la cultura como "nacional" desde una perspectiva homogeneizadora e integradora. Las revistas artístico-culturales ponen en escena el ingreso de universos socioculturales otros, que no forman parte del campo cultural de la época y que, por lo tanto, lo tensionan y fracturan. Son, por ende, objetos que en sí mismos reflejan el carácter plural de nuestra literatura y de la heterogeneidad que subyace, de alguna u otra forma, bajo toda producción cultural latinoamericana.

\section{VANGUARDIA HETEROGÉNEA O DE LUGARES LOCALES INTERMEDIOS}

\subsection{Revista Litoral: retórica del desfase}

La revista Litoral: Órgano de estética, arte moderno y ciencia irrumpe en el campo cultural de la década como un fenómeno completamente nuevo. El primer número se publica en Valparaíso en noviembre de 1927, el segundo en diciembre de ese mismo año y el tercer y último número en marzo de 1928. Estas tres publicaciones -que ya de por sí son un mérito en lo que a revistas de vanguardia se refiere- constituyen un fiel reflejo del cruce e hibridación de paradigmas culturales producto del tránsito. En Litoral publican poetas modernizadores y dislocantes como Pedro Plonka, Julio Walton y Salvador Reyes, junto a voces modernistas, mundonovistas e incluso tardorrománticas, como serían Zoilo Escobar, Alejandro Gutiérrez y Luis Enrique Délano.

Estos artistas, cada uno a su modo, darán cuenta del desfase ruralidadmodernidad, contrastando y tensionando en sus obras estos dos sistemas so- 
cioculturales y evidenciando, con ello, una heterogeneidad histórica y cultural a través de estrategias discursivas. Lo anterior será llevado a cabo a través de un vanguardismo con un fuerte sustrato mundonovista ${ }^{6}$, existiendo en algunos casos poemas definitivamente vanguardistas, pero de diversos registros entre sí: futuristas o de nueva sensibilidad, centrados en una nueva percepción espacial, lineales o repletos de yuxtaposición y experimentación formal.

Hay en Litoral un fuerte sustrato rural que disloca un imaginario de modernidad urbana y tecnológica, lo que se verá reflejado en la mayor parte de las producciones de la revista que, en su conjunto, conforman un todo heteróclito de discursos culturales. Como ejemplo de lo anterior, el poema en prosa "Evocación en la noche" de Pedro Celedón, constituye una visión fantasmagórica y espeluznante de la máquina en la gran ciudad, donde el poeta-vate, en un estado de vigilia, intentará advertir del desastre antes de que éste ocurra: "Ahí, al pie del corte a pico del cerro, está la Casa de Máquinas, Negra, siniestra, desbordante de tinieblas y resplandores...Adentro, como en sofocantes galerías de cavernas que se cruzan, hay quietas locomotoras negras, como monstruos colosales, ceñidas con sus tuberías de cobre y bronce que relucen, que jadean, que resoplan al compás y aceleradamente" (1927: 9). La locomotora es descrita como monstruo colosal, infernal madriguera, tórax negro de una boa gigante, dragón de hierro; a ratos no son una, sino dos locomotoras, acopladas como macho y hembra, “...una arrastrando a la otra como reptantes y horribles vibriones... que se arrastran al pie del corte abrupto del cerro, le sacuden con sus alaridos restallantes, le estremecen hasta las entrañas, con sus crujidos estruendosos..." (1927: 9-10). En esta oscuridad silenciosa, la máquina se incrusta en una naturaleza virgen, escena que también se repite en el poema "Typperary" de Pedro Plonka, cuyo escenario, el puerto, entregará una visión igualmente cruda de la irrupción de la técnica en la ciudad: "Allá están los ocasos clavados/ y las auroras amanecen fumando/ las locomotoras perforan túneles resonantes.../ Film de las marinerías vendimiando en las radas/ en donde las chimeneas aran el campo azul/ de oro y estaño es el rostro de los puertos..." (1927: 11).

Este vaivén entre ruralidad y urbanidad hace emerger un doble estatuto sociocultural que se ve reflejado en los discursos visuales de la primera y

${ }^{6}$ El mundovismo o posmodernismo literario es un movimiento poético de transición situado entre el modernismo y las vanguardias. Como reacción al modernismo, el mundonovismo se centra en lo propio (espíritu, tierra y ambiente americano) y utiliza expresiones sencillas y un lenguaje coloquial. No obstante, se distancia del nacionalismo literario, pues esta inmersión en lo telúrico provoca en el poeta una conexión con lo trascendente. Este último aspecto, la unión entre lo rural y lo espiritual, será retomado por poetas posteriores (Neruda, De Rokha, Mistral) y le dará a la vanguardia su sello local. Ver: Concha, Jaime (1998: 11-23). 
segunda portada de la revista: mientras el linóleo del mexicano Jesús Carlos Toro representa las metrópolis, fábricas y máquinas, es decir, el dinamismo en la vida de la gran ciudad, por su parte, el grabado de Germán Baltra pone en escena un paisaje bucólico, de intimidad agreste, que bien podría funcionar como paratexto del poema "El canto de las voces silvestres" de Zoilo Escobar: "Y suspiro pensando en la prodigalidad de las tierras centrales y las praderas mías/ ¡donde es tan dulce el mirar de las campesinas!” (1927: 15).

En relación a esto último, cabe decir que la distancia entre ambas portadas se debe no sólo a una cuestión temática-ciudad versus campo-, sino también al modelo de representación que cada una de ellas utiliza: mientras el grabado de Toro representa la ciudad al modo del constructivismo ruso -con verticales y diagonales que orientan topológicamente a los edificios y la imitación del fotomontaje-, por su parte Baltra continúa en su imagen con una lógica representacional mimética, sostenida en la linealidad discursiva, sin imponer -como sí lo hace Toro- una lógica asociativa en el lector.

De este modo, junto a una heterogeneidad temática o de contenido -donde, a grandes rasgos, el imaginario urbano moderno se enfrenta e infiltra en una naturaleza rural y prístina-, en Litoral se desarrollará paralelamente una heterogeneidad formal, cuyo doble estatuto sociocultural surgirá en el desfase entre mundo representado y sistema o modo de representación. Así, y producto de procesos modernizadores a destiempo y en diferentes espacios, la heterogeneidad formal surgirá en gran parte por lo que Schwartz (1983) denomina "cosmópolis referencial": “...lo cosmopolita podrá aparecer bajo una forma puramente referencial...o como un intrincado sistema textual de cruces histórico-lingüísticos" (17), esto es, un cosmopolitismo puramente denominativo y descriptivo que no alcanza el plano textual, autónomo y metalingüístico.

Como ejemplo de lo anterior, el manifiesto/poema del número dos de la revista atiende a la ciudad, a su vértigo, multitudes, publicidad y actividad portuaria: “...el carraspeo de los klaxons, la balumba polífona del bocinaje, el crujido continuo, la rotación incesante, el bracear de los grandes donkeys sobre los muelles como gimnastas de acero, vertiginosos como el ir y venir de los trenes..." (1927: 32), pero todo lo anterior; todo lo "parpadeante", "sorprendente" y "vertiginoso" no se convierte en escritura. Hay la sola descripción de aperturas culturales, pero no una ruptura sintáctica y semántica, es decir, una modernidad que si bien es de interés temático, carece por completo de conciencia en el plano de la composición.

De manera similar sucede en el poema de contenido futurista "Auto", de Salvador Reyes, publicado en el número tres de Litoral: "Nuestra piel es la 
pista de las velocidades/ flecos de viento flamean en torno a nuestro cuerpo/ un ritmo preciso acompaña el vértigo de las cosas.../con la velocidad que se le impone/ mientras el cielo gira pausadamente sus aspas/ como un ventilador descompuesto" (1928: 5). Contenido futurista, pero estructura poética rígida y convencional. En términos de García Canclini (2001), una "heterogeneidad multitemporal", en tanto el desfase entre un referente futurista y una estructura convencional, rígida y rítmica, no hace más que revelar la fricción entre dos temporalidades artístico-históricas: modernismo y vanguardismo o, más ampliamente, tradición y modernidad. Si bien lo anterior es extensivo a gran parte de las revistas de vanguardia de la época, la particularidad de los poetas y artistas de Valparaíso reside en la interiorización de estos cambios modernizadores como una experiencia heterogénea, traumática y contradictoria: del campo a la ciudad, del sedentarismo al nomadismo. Cambios que se viven con escepticismo, a diferencia de los vanguardistas de Santiago, quienes, en su mayoría, se incorporan con fascinación a la vorágine moderna.

De modo que en todos los poemas e imágenes de Litoral el espacio no es la urbe definitiva, sino lo rural en transformación y lo urbano semiindustrial, registrando los procesos heterogéneos de modernización a través de una "retórica del desfase": entre el mundo representado y el modelo de representación, entre tradición y modernidad, entre procesos modernizadores a destiempo y en diferentes espacios. En síntesis: una estética influida por lo nuevo, pero situada en una realidad semiindustrial y urbana, que recibe el influjo extranjero -o, en términos de Cornejo, al universo sociocultural otro- desde la incomodidad y el roce.

Lo anterior se ve reflejado, sobre todo, en el poema "Ciudad despanzurrada" de Julio Walton: "Domingo/ acción de clínica a ciudad embarazada/ seis martillazos de 21 horas" (1927: 14). La ciudad sobrepoblada es "despanzurrada" y como consecuencia de ello, pare hombres que caen en la "sonda" de los trenes7. Lo que sigue es una sucesión de intensas imágenes sobre Valparaíso, intercaladas con escenas del aborto a la ciudad, la que luego es personificada en la figura de una mujer: "La novia se quedó/ con las luces prendidas/ en las entrepiernas". En torno a esta ciudad, y como causas del desbarajuste, varias escenas de un Valparaíso cosmopolita, rodeado e inva-

7 El poema de Walton recoge la imagen del aborto urbano del poema expresionista "El dios de la ciudad" de Georg Heym, influencia que habría estado motivada por la presencia del húngaro expresionista/activista Zsigmond Remenyik en el grupo vanguardista de Valparaíso. Sobre la apropiación expresionista en Valparaíso ver mi trabajo: "La otra vanguardia: el expresionismo de Valparaíso en su revista Litoral'. 
dido de extranjería -la nurse de los niños, avisos luminosos de Weir Scott, Salvation Army - para finalizar con el cine hollywoodense que aparece como el último inmigrante de una cadena maligna que consumará esa primera acción sangrienta: "Sobre el cine/ los últimos niños descolgados/Tom Mix/ pistoletea en las cabecitas/de colores" (15).

Así entonces, el imaginario vanguardista porteño construye a su ciudad como un escenario infernal y apocalíptico que escapa al dominio del hombre; saturada tanto de inmigrantes extranjeros que han invadido física e ideológicamente el puerto, como de la muchedumbre y el humo producto de la industrialización. Saturación y fracaso de un proyecto moderno -encarnado en la metrópoli-, que al no sostenerse sobre sí mismo, colapsa.

\subsection{Revista Nguillatún: desde lo aborigen a lo universal}

Son escasas -sino nulas- las menciones a una vanguardia indigenista en Chile, desarrollada al alero del puerto. Caso extraño y aislado, su único proyecto fue liderado por el músico porteño Pablo Garrido y el poeta antofagastino Neftalí Agrella en 1924 con el nombre de Nguillatún, Periódico de Literatura y Arte Moderno, el que buscaba acoplarse y, a un mismo tiempo, distanciarse del movimiento indigenista peruano asociado a Mariátegui. En primer lugar y si bien ambos pueden calificarse como "heterogéneos", la diferencia con la incipiente y fugaz ${ }^{8}$ vanguardia indigenista porteña radicará en que en ella confluyen dos sistemas socioculturales completamente opuestos: indigenismo y cosmopolitismo.

El manifiesto de la revista revela un cambio radical respecto a los postulados de Rosa Náutica ${ }^{9}$ pues da cuenta de la transición de los artistas del puerto desde el polo cosmopolita al identitario, desde los ismos europeos a un arte nacionalista de base indígena; de allí que el título de la revista aluda a una ceremonia religiosa mapuche: "Si mediante la belleza literaria

${ }^{8}$ Cabe decir que el único número de la revista Nguillatún se publicó el 6 de diciembre de 1924. Sin embargo, a este proyecto fugaz pueden asimilársele otros textos de Agrella, entre ellos El alfarero indio (1933), conjunto de relatos que continúa su interés por las raíces vernáculas.

9 En mayo de 1922, el llamado Movimiento Vanguardista Chileno publica el manifiesto "Rosa Náutica" en Antena, Hoja vanguardista, con el respaldo de artistas e intelectuales chilenos de Valparaíso y Santiago, de extranjeros residentes en Valparaíso y con las adhesiones de latinoamericanos cosmopolitas como Borges, Maples Arce, Huidobro y Edwards Bello. En ese entonces, el grupo se adscribe al espíritu nuevo de Apollinaire, Marinetti y Huidobro y tanto el lenguaje como las alusiones y citas del manifiesto dan cuenta de su cercanía con estos tres escritores faro y con el estilo e imaginería de la vanguardia española. 
elevamos la significación vital de nuestra raza a un plano de idealismo, toda su expresión como entidad étnica constituirá el filón propio de un arte, que será criollo y universal a un mismo tiempo" (1924: 1).

El programa de la revista es múltiple y se dedica, por una parte, a los cantos, música, danza y costumbres araucanos y, por otra, a diversas corrientes filosóficas e ismos de la vanguardia. Sin embargo, lo interesante de esta propuesta no es tanto la hibridación de dichos objetos, aparentemente disímiles, sino, justamente, la ausencia de hibridación en el ejercicio de la revista. Me explico: si bien central, la problemática indígena se sitúa en Nguillatún únicamente a nivel programático y teórico: en el título y manifiesto de la revista y en artículos expositivos sobre costumbres araucanas: "Los cantos araucanos son muy antiguos. El cronista Núñez de Pineda y Bascuñán, prisionero de los araucanos en 1629, hace referencia a cada paso de las canciones que los indios entonaban..." (1924: 4), pero se mantiene completamente ausente de la actividad creadora de los poetas que allí publican.

$\mathrm{Al}$ respecto, cabe mencionar que la osadía de convertirse en mediadores y difusores del arte nuevo en Valparaíso en 1922, provocó gran resistencia en el campo cultural porque el horizonte de expectativas de recepción y valoración artísticas, así como las ideas y criterios operantes, eran los del nacionalismo literario. Como afirma Lizama (2012: 46), la acusación de "infelices imitadores" a este movimiento, conduce a sus líderes a modificar su proyecto, por lo que, de cierta manera, el manifiesto de Nguillatún es la confesión de una derrota: Agrella y Garrido se subordinan a las restricciones del campo cultural porque entienden que el manifiesto de Rosa Náutica no tiene cabida. Quizás por esto último la inclusión de la problemática aborigen no se resuelve y el arte, a un mismo tiempo "criollo y universal" que el grupo Nguillatún propone, termina siendo -podemos inferir- una heterogeneidad forzada, en la cual los sistemas socioculturales implicados, tradición y modernidad, se representan como verdaderas fuerzas en pugna y no como parte del "arco iris ideológico" (1924: 1) del hombre nuevo: los cantos araucanos aparecen junto a crónicas de la música en Alemania, Francia y Brasil y junto a poemas de poetas porteños y reflexiones sobre música y danza europeas, pero este planteamiento de progresión desde lo aborigen a lo universal; esta multiplicidad discursiva, no logra plasmarse de manera armónica porque y resulta un ejercicio más bien superpuesto e incoherente.

A pesar de esto último, la heterogeneidad no queda exenta del proyecto Nguillatún y puede entenderse mejor, bajo otros parámetros, en un poema de Neftalí Agrella llamado "La gran Rueda", el que fue publicado en la re- 
vista junto a una breve crónica explicativa y un grabado de Lautaro Alvial.

Ambos textos, poema y crónica, se complementan para revelar algunas modalidades de apropiación de la modernidad: la rueda de Chicago llega a Valparaíso en 1922 y es parte de una muestra mayor proveniente de Coney Island, Nueva York, de allí el nombre de la muestra: Coney Island Shows. Un año más tarde regresa a Valparaíso y en 1924 va de gira a Curicó, pero en esta ciudad se llama Luna Park (Lizama, 2012: 47). Este cambio y el nuevo nombre que enfrenta a dos culturas, es un primer índice de una tensión irresuelta y del roce entre lo ajeno y lo propio que se profundiza en los textos, y que revela las abisales diferencias que separan y contraponen, hasta con beligerancia, a los varios universos socioculturales.

En el contexto de la experiencia de la metrópoli, leemos en la crónica que la rueda se coloca en Santiago en "la avenida de las Delicias" (1924: 3) y allí se encuentra "sola como un exorbitante árbol que sobrepasara la ciudad". Junto al arraigo de la gran ruega -acuden a ella "familias endomingadas y novios de feria"-, la extrañeza y la desarmonía con el entorno hacen que el poeta la conciba como un "edificio imaginado por un arquitecto absurdo" y un "ferrocarril interplanetario", lleno de dinamismo y energía que "da vueltas como un planeta".

De este modo, la heterogeneidad que pone en escena Nguillatún surgirá por el roce entre lo ajeno y lo propio y la tensión del arraigo con el desarraigo. Por una parte hay una hibridación horizontal forzada, sociocultural, étnica y lingüística: Valparaíso es el gran puerto del Pacífico Sur y, en el imaginario de los poetas y artistas del puerto, se encuentra rodeado e invadido de extranjería. Pero, cabe destacar, lo anterior traerá consigo una hibridación vertical, con la convivencia de distintas temporalidades de manera coetánea, premodernidad y modernidad, lo que es vivido por los poetas como una experiencia abrumadora y confusa, como bien lo refleja el poema "Torbellino" de Pedro Plonka: "En la marea de la orquesta/ tiene vaivén de transatlántico el/ Dancing-hall.../ Las cascadas eléctricas/ despeñándose contra el parquet/ lanzan torbellinos de luciérnagas/ sobre las serpientes musicalizadas..." (1924: 2).

\section{A MODO DE CONCLUSIÓN}

La vanguardia de Valparaíso constituye un nicho artístico e intelectual aparte, que asume e interpreta su espacio local al construirlo simbólicamente con figuras, formas e imágenes, las que luego se traspasarán a la conciencia/ 
inconsciencia colectiva: espacios miserables, locomotoras macabras, metrópolis a punto de estallar, marineros borrachos, industrias que cobran vida propia, dancing-halls y avisos luminosos, litorales constelados de mástiles, nonatos colgando de un vientre sangriento, mares lejanos, prostitutas y mendigos, noches temerosas, radas rojas de vino, ciudades caídas de los rascacielos.

Estos poetas y artistas amotinaron de imágenes la modernidad porteña y contribuyeron al proceso de mitificación del puerto de Valparaíso como ciudad del caos y la degeneración; escenario infernal que consolidaría su carácter simbólico ambivalente entre ciudad fascinante y amenazadora; entre gran puerto del Pacífico Sur y espacio residual de la modernidad. En otras palabras, sujetos que asumieron su propio proceso de modernización desde la oposición, como contradicción radical y ríspido contraste (Cornejo Polar, 2011: 73).

Volviendo a Cornejo Polar, lo interesante de sus "literaturas heterogéneas" para el caso chileno consiste, justamente, en que permite realizar una lectura sincrónica relacional -en palabras del teórico "historiar la sincronía" (11) - que da cuenta de aquellos subsistemas, tipificados y caracterizados, que la tensionan. Tal es el caso de Valparaíso, subzona cultural de la década del veinte, cuyas revistas artístico-culturales ponen de manifiesto el conflicto y ambigüedad a partir del encuentro entre dos universos y, desde allí, el surgimiento de una vanguardia heterogénea, completamente distinta a la que se desarrolló en la metrópoli y que bien podríamos definir -haciendo eco a lo propuesto por Cornejo Polar (2011) - como "vanguardia de lugares locales intermedios".

La diferencia entre los grupos de Santiago y provincias revela una apropiación diferenciada de los discursos de la modernidad, lo que complejiza y enriquece la pluralidad del campo artístico y cultural de la década: mientras los primeros se desplazan físicamente hacia la modernidad artística central, o bien reciben a quienes han viajado; por su parte, puertos como Valparaíso se convierten en verdaderos "caldos culturales" gracias a la llegada de migrantes extranjeros que traen consigo el conocimiento directo de los movimientos a los que adscriben y permiten la circulación, discusión y apropiación activa de estas nuevas ideas. Todo lo anterior produce una polifonía compleja, en la que se advierte una distancia entre la provincia, más distante y escéptica ante el "ruido modernólatra", y la capital más comprometida con los cambios.

Los grupos amparados bajo los proyectos Litoral y Nguillatún dan cuenta 
de una de las dos orientaciones fundamentales que Raymond Williams reconoce en el período moderno; aquella que comprende los cambios que están reformando la sociedad; orientación a la que paralelamente le acompaña una actitud respecto del lenguaje, comprometido con las formas heredadas y considerado como material dentro de un proceso social (Williams, 1989: 51). En Valparaíso no existen modernólatras, sino al contrario: sujetos críticos respecto a su propio proceso de modernización, con un sentido de futuro y una estética indisociable de una ética, lo que los transforma en poetasvates que advierten la inminencia del desastre antes de que éste ocurra; así, Walton se refiere al colapso y desbarajuste de una metrópoli cosmopolita en "Ciudad despanzurrada", mientras que Celedón se espanta con su propia visión sobre una humanidad que es conducida inconscientemente por el espíritu infernal de la máquina.

Todos estos artistas asumen una perspectiva beligerante y enfatizan la incompatibilidad de sus traumáticas interrelaciones, instalándose en el espacio común de la contradicción -Valparaíso como ciudad amenazante y fascinadora- y asumiendo como objeto de conocimiento esa oposición desde una perspectiva crítica. De este modo, los textos e imágenes de los artistas del puerto constituyen espacios linguísticos en los que se complementan, solapan, intersectan o contienden discursos de muy varia procedencia de una manera no armónica (Cornejo Polar, 2011: 11): mundonovismo, expresionismo alemán, modernismo, tardorromanticismo, constructivismo ruso, etc. Un universo heteróclito de discursos culturales que tensionan el mismo sistema literario y una realidad fracturada -producto de la modernizaciónque se representa al interior de su literatura.

Así entonces, y mientras las elites y la 'intelligentzia' tienen ciertas concepciones de la temporalidad y se adjudican el relato de "lo nacional", por su parte, las revistas artístico-culturales, sobre todo las de provincia, funcionan como pulsiones contrahegemónicas de negociación y confrontación frente a este escenario nacionalista, a través de la construcción de un "nosotros" que busca su propia representación del tiempo nacional y sus propias configuraciones del pasado, presente y futuro.

Los artistas del puerto articulan estas tensiones y concepciones de la temporalidad a partir de un contenido crítico y polémico y una estrategia, a lo menos, beligerante. En su lugar se expresan, por una parte, las tensiones ideológicas, las relaciones polémicas y las luchas por la conquista del poder simbólico y, por otra, un imaginario discursivo que, a grandes rasgos, constituye una crítica del pasado y una propuesta de futuro subjetiva y utópica. 


\section{REFERENCIAS}

Alberdi, Begoña. (2012.) La otra vanguardia: el expresionismo de Valparaíso en su revista Litoral. Mapocho, 71, 51-71.

Altamirano, Carlos y Beatriz Sarlo. (1984). Literatura/Sociedad. Buenos Aires: Hachette.

Bourdieu, Pierre. (1987). Los tres estados del capital cultural. Sociológica, 5, 11-17.

. (1995). Las reglas del arte. Génesis y estructura del campo literario, Barcelona: Anagrama.

Concha, Jaime. (1998). Función histórica de la vanguardia: el caso chileno. Revista de Crítica Literaria Hispanoamericana, 48, 11-23.

Cornejo Polar, Antonio. (2011). Escribir en el aire: Ensayo sobre la heterogeneidad socio-cultural en las literaturas andinas. Lima: CELACP.

García Canclini, Néstor. (2001). Culturas hibridas: Estrategias para entrar y salir de la modernidad. Buenos Aires: Paidós.

Litoral 1 y 2. (1927, 1928). Valparaíso.

Lizama, Patricio (2012). Vanguardia chilena: manifiestos, revistas e intelectuales. Mapocho, 71, 31-49.

Moraña, Mabel. (2004). Revistas culturales y mediación letrada en América Latina. En Critica impura (pp. 239-246). Madrid: IberoamericanaVervuert.

Nguillatún. (1924). Valparaíso.

Patiño, Roxana. (2008). Revistas literarias y culturales. En La teoría literaria hoy: Conceptos, enfoques, debates (pp. 145-158). Buenos Aires: Al margen. Rama, Ángel. (1982). Transculturación narrativa en América Latina. México D.F: Siglo Veintiuno Ediciones. . (2004). La ciudad letrada. Santiago: Tajamar Editores.

Schwartz, Jorge. (1983). La cosmópolis: del referente al texto. En Vanguardia y cosmopolitismo en la década del veinte: Olivero Girando y Oswald de Andrade (pp. 13-58). Rosario: Beatriz Viterbo Editora.

Szurmuk, Mónica y Robert McKee Irwin. (2009). Diccionario de estudios culturales latinoamericanos. México: Instituto Mora/Siglo XXI Editores.

Williams, Raymond. (1989). El lenguaje y la vanguardia. En J. Culler, J. Derrida, S. Fish y F. Jameson, La lingüistica de la escritura (pp. 41-56). Madrid: Visor. 